\title{
Epizootiology, laboratory and virulence analyses during the emergency phase of the African swine fever eradication program in Brazil in 1978: a historic account
}

\section{Epizootiologia, análises laboratoriais e de virulência durante a fase emergencial do programa de erradicação da peste suína africana no Brasil em 1978: um relato histórico}

\author{
Tânia Maria de Paula Lyra'; Tânia Rosária Pereira Freitas ${ }^{2 *}$
}

\begin{abstract}
After the first African swine fever (ASF) outbreak occurred in Brazil in 1978, an official laboratory for ASF diagnosis (ASFDL) was established. The current work reviews the efforts of the laboratory team to define an ASF diagnosis during the emergency phase of the ASF Eradication Program. From June to December 1978, 3,803 samples of pig tissue, blood and serum were analyzed. ASFDL first isolated the ASF virus (ASFV) from pig tissue samples from the Teresópolis municipality in the Brazilian state of Rio de Janeiro. During the first two months, ASFV was isolated from 130 of 320 (40.62\%) pig samples analyzed by haemadsorption (HAD), indicating that the outbreak had reached 96 of 214 municipalities surveyed throughout the country in that period. The distribution of positive ASFV samples indicated the potential route of virus dispersal. Because of the rapidity of the actions implemented against ASF, the number of ASFV positive samples decreased from $48.36 \%$ in June to $33.53 \%$ in July, and then to $0 \%$ in August 1978. In parallel, ASFV antibody detection increased from $17.89 \%$ in June to $52.04 \%$ in August 1978. In the state of Paraná, a comparison of ASFV isolates with descriptions of the disease, and a rapid decrease in mortality rates suggested the occurrence of a low or moderate virulence ASFV strain. Establishment of ASFDL was crucial for the program, which eradicated ASFV from the country within six years of the first outbreak. Advances in cellular and molecular biology corroborated pioneer studies regarding ASFV virulence, and have highlighted the importance of establishing and maintaining secure measures to prevent ASFV reintroduction to the country. Information on virulence heterogeneity in ASFV populations during outbreaks provided a paramount tool for the adoption of eradication best practices.
\end{abstract}

Key words: African swine fever, epizootiology, haemadsorption, virulence, Brazil

\section{Resumo}

\begin{abstract}
Após a ocorrência do primeiro surto de peste suína Africana (PSA) no Brasil, o laboratório oficial de diagnóstico de PSA (LDPSA) foi implantado. O trabalho atual revisa o esforço da equipe de laboratório para estabelecer o diagnóstico de PSA na fase emergencial do programa de erradicação. De Junho a Dezembro de 1978, 3803 amostras de tecido, sangue e soro de suínos foram analisadas. O primeiro isolamento do vírus da peste suína africana (VPSA) realizado pelo LDPSA foi feito em amostras de suínos oriundas da cidade de Teresópolis no Estado do Rio de Janeiro, Brasil. Em todo
\end{abstract}

1 PhD. Consultora em Defesa Agropecuária. Confederação Nacional de Agricultura e Pecuária do Brasil, CNA. Brasília, DF. Brasil. E-mail: tanialyra@terra.com.br

2 PhD. Pesquisadora em Ciências Exatas e da Natureza. Laboratório Nacional Agropecuário, LANAGRO/MG, Ministério da Agricultura, Pecuária e Abastecimento, MAPA. Pedro Leopoldo, MG, Brasil. E-mail: taniafrei@hotmail.com

Author for correspondence 
país, nos primeiros dois meses, de 320 amostras analisadas, 130 (40.62\%) foram positivas pelo teste de hemadsorção o que sugere que a infecção com VPSA alcançou suínos em 96 dos 214 municípios analisados no período. A distribuição dos isolamentos do vírus no país mostrou uma possível rota de dispersão viral. Devido à rapidez das ações de eliminação dos focos, o número de amostras positivas caiu de 48,36\% em Junho para 33,53\% em Julho até nenhuma em Agosto, de 1978. Paralelamente, a detecção de anticorpos aumentou de 17,89\% a 52,04\% de Junho para Agosto de 1978. Os isolamentos do vírus pela técnica de hemadsorção (HAD) quando comparados com a descrição da doença e o forte declínio na taxa de mortalidade no Estado do Paraná sugeriram a ocorrência de cepas virais de VPSA de baixa a moderada virulência. A implantação do LDPSA foi crucial para o programa que assegurou a erradicação do VPSA em todo país após seis anos do primeiro surto. Os avanços na biologia celular e molecular corroboraram as suposições dos estudos pioneiros sobre a virulência viral e alertam para a importância de se estabelecer e manter medidas de segurança para prevenir a reintrodução do VPSA no país. A informação sobre heterogeneidade na virulência das populações virais nos surtos fornece uma ferramenta fundamental para a adoção de melhores medidas de erradicação.

Palavras-chave: Peste suína africana, epizootiologia, hemadsorção, virulência, Brasil

\section{Introduction}

African swine fever (ASF), first described in Kenya in 1921 (MONTGOMERY, 1921), is a hemorrhagic viral disease that affects wild and domestic pigs of all breeds and ages. The high morbidity and mortality rates associated with ASF and the lack of preventive vaccines make the disease one of the major causes of economic losses to pig farmers, and a central issue for global food security (ARZT et al., 2010). ASF infection of domestic pigs can occur in peracute, acute, chronic and subclinical forms, depending on viral strain virulence and host factors (NEILAN et al., 2002). Initially endemic to sub-Saharan African countries, the ASF virus (ASFV) has spread rapidly into countries never before infected (BASTOS et al., 2004). In 2007, ASF reached Georgia in the Caucasus region before spreading to neighboring countries (PENRITH; VOSLOO, 2009). The first official notice of ASF in Russia was in November 2007, and since then more than 900,000 pigs have died (MALOGOLOVKIN et al., 2012). Accumulated worldwide losses from ASF were an estimated US $\$ 1$ billion in 2012 (World Organization for Animal Health - OIE, 2012). The FAO and the OIE have warned of the risk of ASF reaching China, and have conducted outbreak simulations in several countries.

The African Swine Fever Virus (ASFV) is a complex icosahedral, cytoplasmic, linear double- stranded DNA, lipoprotein-enveloped, arbovirus from the Asfarviridae family, Asfivirus genus (DIXON, 1986; IYER et al., 2006). The genome of several ASFV strains has been completely sequenced and consists of a linear double-stranded T-A rich DNA molecule ranging between 170 and $190 \mathrm{kbps}$, depending on the isolate, and containing hairpin loops as well as terminal inverted repeats (CHAPMAN et al., 2008). High virulence virus strains cause ASF in the peracute and acute forms, which develop into a severe acute hemorrhagic fever with death rates nearing $100 \%$ in 2-10 days, sometimes even before clinical signs are observed and an antibody response is mounted (MAC DANIEL, 1981; MEBUS et al., 1981). Sub-acute, chronic and unapparent forms of infection are associated with low virulence strains, which elicit antibody production (LYRA, 1980). Subclinical ASF infections are difficult to distinguish from classical swine fever (CSF) (MEBUS; SCHAFLER, 1982). Chronic ASF infection occurs in a variety of forms and can persist for several months without clinical signs. Recovered ASFV-carrier pigs and persistently-infected pigs pose an obstacle to disease control (HESS, 1981). European wild boars and feral pigs have similar clinical signs and mortality rates as those seen in domestic pigs (OURA et al., 1998). Argasidae ticks of the Ornithodoros genus, which infest the African wild pig warthogs (Phacochoerus africanus), play an important role in 
maintaining ASFV in nature (BASTO et al., 2006; BOINAS et al., 2004). In Brazil, the first reported ASF case occurred on the Floresta pig farm in the municipality of Paracambi, Rio de Janeiro, on May, 1978 (LYRA et al., 1986). The epidemiological, economic and surveillance aspects of ASF outbreak eradication have been described by Lyra (2006). Extending this previous study, we review here the efforts of the Brazilian ASF Diagnostic Laboratory (ASFDL) to establish the ASF diagnosis during the initial six-month emergency phase of the eradication program (1978), when the ASF virus was isolated in several outbreaks (MINISTÉRIO DA AGRICULTURA, 1984). We emphasize the aspects of ASFV isolation and dispersion throughout the country, which indicated that the Brazilian ASF outbreaks were caused by an ASFV strain of low to moderate virulence.

\section{Materials and Methods}

\section{ASF occurrence data}

ASFDL registration data were acquired from the former National Animal Reference Laboratory (LANARA). Some of the data were provided by the libraries of the Rio de Janeiro and Minas Gerais Federal Universities in Brazil. Several official documents from Dr. T. Lyra's personal files were also consulted. Pig tissue and serum samples were collected from registered pig herds with at least one pig presenting suspicious clinical signs of ASF (LYRA et al., 1986; MACHADO JUNIOR, 1990). From June 1978 to April 1982, 41,829 samples were collected from pigs from the Northern, Northeastern, Central, Southern and Southeastern regions of Brazil. From June 12 to December 28, 1978, 3803 pig tissue, blood and serum samples were sent to ASFDL and were identified by number, arrival and test dates, municipality, state, farm ownership, and health inspector's name. We also investigated 559 epidemiological surveillance records (FORMS): 283 filled out between June and December 1978; 158 during 1979; 82 during 1980, and 36 during
1981. To understand ASFV dissemination in the state of Rio de Janeiro, municipalities where ASF outbreaks occurred were geographically distributed in mesoregions for proximity and cultural grouping. ASFV spread from the Southeastern to other regions was visualized on a map of Brazil on which all municipalities affected by ASF were plotted.

\section{ASF diagnosis data}

During the first month of its establishment, between June 12 and July 10, 1978, ASFDL implemented ASFV laboratory diagnostic practices following OIE Standards (Office International des Epizooties - World Organization for Animal Health). The laboratory detected virus-positive samples using haemadsorption (HAD), a technique that relies on the property of infected leukocytes to induce erythrocyte adsorption. In parallel, the ASFDL team prepared suspensions of pig organs and tissues preferentially targeted by the virus such as tonsils, lymph nodes, spleen and liver. Each tissue suspension was inoculated on swine leukocyte cultures, and 24 to $72 \mathrm{~h}$ later a swine erythrocyte suspension was also inoculated on the leukocyte cultures (HESS; OETRAY, 1960; MALMIQUIST, 1962). The fluorescent antibody test (FAT) or direct immune fluorescence (DIF) techniques were used to detect the ASFV antigen in tonsils, lymph nodes, spleen, and liver by impression smears of tissues, or on buffy coat cells on glass slides (BOOL et al., 1969). Immunoelectroosmophoresis (IEOP) was the standard serological test extensively applied to screen for antibodies against ASFV in pigs from different regions (ANDRADE, 1980; PAN et al., 1972). Implementation of CSF virus (CSFV) differential diagnosis began on July 10, 1978. Pig tissue suspensions were inoculated in the porcine kidney cell line PK15, and CSFV was detected 24,48 and $72 \mathrm{~h}$ post-inoculation by indirect immune fluorescence (IIF). The CSFV diagnosis was also performed by FAT. Dr. J. L. H. Facchini and his group in the Parasitology Department of 
the Rural Federal University of Rio de Janeiro (UFRRJ) intensively screened for Argasidae in pig smallholdings with inferior housing facilities and poor sanitary conditions in Rio de Janeiro, where several ASF foci had occurred. Fortunately, they did not detect soft ticks of the genus Ornithodoros in pigs, which made possible complete elimination of the disease without the persistence of viral reservoirs in the ecosystem.

ASFV isolation, disease description and mortality rates in the state of Paraná

The FORMS filled out during the emergency phase of the ASF eradication program in the state of Paraná (PR) registered 59 pig herds from 43 municipalities during June and July of 1978. From these herds, 58 pig samples were tested by HAD. In June and July, 1978, respectively, 11 and 9 FORMS with one pig herd/FORM registered the isolation of ASFV.

Number of passages needed for ASFV isolation by HAD, description of ASF pathogenic signs, and mortality rates were compared for the characterization of heterogeneity in the viral population. Results and field information from the PR municipalities where ASF was surveyed and ASFV was isolated by HAD were plotted on a map.

\section{Results and Discussion}

\section{Distribution of ASF outbreaks in Brazil}

The ASF combat strategy that was employed can be divided in two phases: the emergency phase, from 1978 to 1979 , and the specific program, from 1980 to 1984 (MINISTÉRIO DA AGRICULTURA, 1984). The ASF emergency phase started immediately after the first outbreak occurred in the municipality of Paracambi, Rio de Janeiro. Several ASF experts from Europe and North America were invited to collaborate in setting up a laboratory for diagnosis of ASF. Drs. William Hess, Keith Shermann and
Joe Kresse (Plum Island Animal Disease Center - PIADC) joined the efforts to establish ASFDL, and Drs. I. C. Pan (PIADC) and A. Ordás (Instituto Nacional de Investigación y Tecnología Agraria y Alimentaria - INIA) contributed to the serology work (ANDRADE, 1980).

In spite of the efforts that led to quick establishment of ASFDL, samples from distant regions sometimes deteriorated before arrival because of the poor transport and communications systems available in 1978. In those cases, the ASF surveillance team had to revisit sites and take new samples, inevitably delaying laboratory results. ASFV was investigated by HAD in different types of samples, including tonsils, lymph nodes, spleen, liver and/or blood. FAT was performed to detect ASFV antigen in tissues and to distinguish the ASFV cytopathic effect (CPE) from that of other swine viruses such as herpesvirus (Aujeszky disease virus). However, FAT lacks sensitivity to detect ASFV antigens associated with sub-clinical and chronic infections, because the antigen-antibody complexes formed in infected tissues block the interaction between virus antigen and antibody test indicator. Thus, HAD was considered the definitive test. The first Brazilian ASF outbreak occurred in the Floresta pig farm, a rustic smallholding in Paracambi, Rio de Janeiro, where pigs often fed on discarded food. Moreover, pigs from different breeds and ages were raised together and confined in a simple house, and the occurrence of other diseases such as salmonella was not uncommon. Most pig farms where ASF outbreaks occurred maintained similar sanitary conditions (LYRA, 1981). Before the ASF diagnosis was confirmed, the owner of the Floresta pig farm has sold pigs and pig products in several establishments in different municipalities in the state of Rio de Janeiro. His trade activities contributed to the dispersion of ASFV within the state (MACHADO JUNIOR, 1990). A commercial establishment in the slum community Nova Brasília in the city of Rio de Janeiro, where the second ASF focus was detected in early June, had acquired live 
pigs from the Floresta farm (MACHADO JUNIOR, 1990). In Nova Brasília, a sow with ASF clinical signs was found scavenging in the community garbage. It was sacrificed and samples were also sent to PIADC where the ASF disease was reproduced and the virus isolated (MACHADO JUNIOR, 1990).

On June 12, 1978, the first five pig spleen samples arrived at ASFDL for ASF diagnosis.
These samples were collected from a sick pig that had fed on a garbage dump in the municipality of Teresópolis. Machado Junior (1990) reported that infected carcasses in the garbage probably originated from the Floresta farm pigs. Two of these samples became the first ASFV isolations performed by the ASFDL team under the supervision of international advisers (Table 1).

Table 1. ASFV diagnostics in the state of Rio de Janeiro between June 12 and July 10, 1978. ASF-HAD-positive samples are distributed by municipality and geographic mesoregions.

\begin{tabular}{cccc}
\hline Municipals of Rio de Janeiro & Geographic & Distance from Paracambi & HAD Positive \\
State $($ RJ) & Mesoregion & $102 \mathrm{~km}$ & 02 \\
Teresópolis & Metropolitan & $319 \mathrm{~km}$ & 08 \\
Campos & North $-\mathrm{N}$ & $91 \mathrm{~km}$ & 01 \\
Alcântara & Metropolitan & $113 \mathrm{~km}$ & 03 \\
Maricá & Metropolitan & $33 \mathrm{~km}$ & 01 \\
Itaguaí & Metropolitan & $103 \mathrm{~km}$ & 01 \\
Itaboraí & Metropolitan & $57 \mathrm{~km}$ & 02 \\
Duque de Caxias & Metropolitan & $88 \mathrm{~km}$ & 03 \\
Niterói & Metropolitan & $316 \mathrm{~km}$ & 03 \\
Bom Jesus Itabapoana & North-East - NE & $24 \mathrm{~km}$ & 02 \\
Barra do Piraí & South $-\mathrm{S}$ & $155 \mathrm{~km}$ & 01 \\
Carmo & Center $-\mathrm{C}$ & & $\mathbf{2 7}$
\end{tabular}

Although Teresópolis is located $102 \mathrm{~km}$ from Paracambi, the two cities were directly connected by roads in 1978, and both are in the same Rio de Janeiro mesoregion. Most ASFV-positive pig samples in the state of Rio de Janeiro came from municipalities easily connected by roads in the Metropolitan Mesoregion, which had intensive truck traffic (Figure 1). Positive samples were also later detected in Barra do Piraí (South Mesoregion), Carmo (Central Mesoregion), Bom Jesus de Itaboapana (Northeastern Mesoregion), and Campos (Northern Mesoregion) (Table 1 and Figure 1). All of these samples came from farms that maintained a rustic rearing system where pigs frequently fed on meat swill.
In face of the ASFV persistence in pork products, and the road trade connection of the initial outbreak sites with Paracambi, it is almost certain that the ASF outbreaks in the state of RJ had the same origin in the Floresta farm. The risk of virus dispersion led investigators to expand virus screening to the states of São Paulo (SP) and Minas Gerais (MG) in the Southeastern region; Paraná (PR), Santa Catarina (SC) and Rio Grande do Sul (RS) in the Southern region and other states in the Northern and Northeastern regions of the country. In June 1978, 74 (48.36\%) of 153 pig samples tested were ASFVpositive (Table 2), including 28 and 7 positive outcomes at the second and third passages in pig leukocyte cultures, respectively. 
Figure 1. ASFV spread through geographic mesoregions of the state of Rio de Janeiro. The first ASF outbreak occurred in the Metropolitan mesoregion and was disseminated to the others by road. Black lines: main roads connecting cities. Mesoregion symbols: M, Metropolitan; N, Northern; NE, North Eastern; C, Central; S, Southern; LC, Lower coastal.

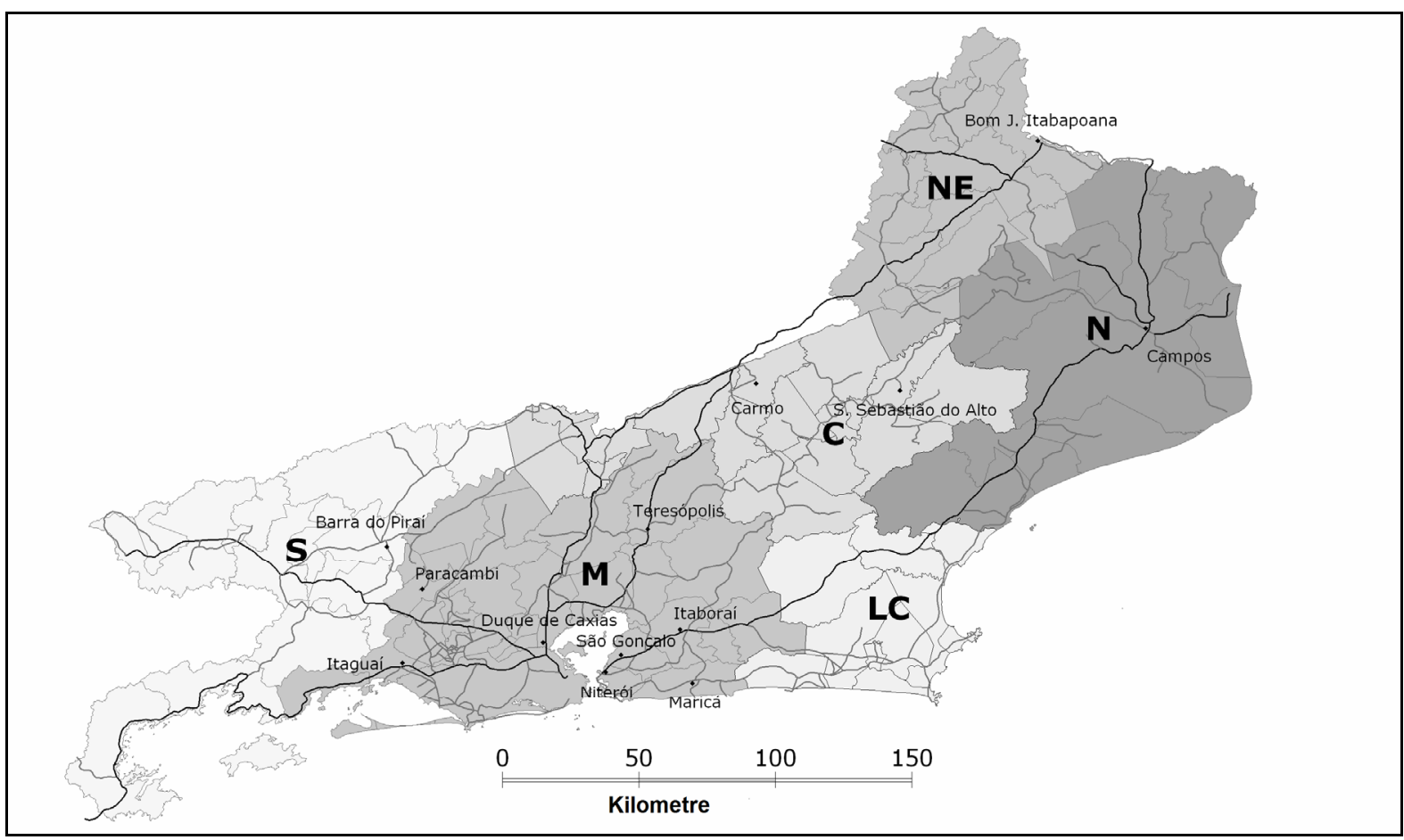

Table 2. ASFV diagnostics in Brazil during the emergency phase of the eradication program: ASF detection by HAD, FAT and serological analysis from June to December 1978 from the entire country.

\begin{tabular}{cccccccc}
\hline \multirow{2}{*}{1978} & \multirow{2}{*}{$\begin{array}{c}\text { Sample } \\
\text { code }\end{array}$} & \multirow{2}{*}{$\begin{array}{c}\text { Sample } \\
\text { received }\end{array}$} & $\begin{array}{c}\text { Positive/ } \\
\text { Tested }\end{array}$ & $\begin{array}{c}\text { Negative/ } \\
\text { Tested }\end{array}$ & $\begin{array}{c}\text { Positive/ } \\
\text { Tested }\end{array}$ & $\begin{array}{c}\text { Negative/ } \\
\text { Tested }\end{array}$ & $\begin{array}{c}\text { Positive/ } \\
\text { Tested }\end{array}$ \\
\hline June & $0001-185$ & 178 & $74 / 153$ & $79 / 153$ & $71 / 143$ & $72 / 143$ & $17 / 95$ \\
July & $187-363$ & 220 & $56 / 167$ & $111 / 167$ & $53 / 163$ & $110 / 163$ & $32 / 102$ \\
August & $365-461$ & 248 & $0 / 171$ & $171 / 171$ & $1 / 119$ & $118 / 119$ & $102 / 196$ \\
September & $493-602$ & 199 & $0 / 155$ & $155 / 155$ & $0 / 88$ & $88 / 88$ & $04 / 179$ \\
October & $590-666$ & 785 & $0 / 154$ & $154 / 154$ & $3 / 86$ & $83 / 86$ & $108 / 769$ \\
November & $667-691$ & 372 & $0 / 41$ & $41 / 41$ & $0 / 21$ & $21 / 21$ & $86 / 361$ \\
December & $692-717$ & 1801 & $1 / 27$ & $26 / 27$ & $0 / 12$ & $12 / 12$ & $107 / 1800$ \\
\hline Total & & 3803 & $131 / 868$ & $737 / 868$ & $128 / 632$ & $504 / 632$ & $456 / 3502$ \\
\hline
\end{tabular}

Most ASFV HAD positive samples came from Southeastern and Southern states (Figure 2). In June 1978, sample groups with the largest proportions of positives in the Southeastern region included 47 samples with 23 positives (48.93\%) from 16 municipalities in RJ; 55 samples with 27 positives (40.44\%) from 33 municipalities in SP; and 10 samples with 4 positives (40\%) from seven municipalities in MG. During the same period, in the Southern region, ASFV was diagnosed in 9 (52.94\%) of 17 pig samples from 15 municipalities in PR; and in 2 (28.57\%) of 7 pig samples from nine municipalities in SC. 
Figure 2. Ninety-six Brazilian municipalities affected by ASF in June and July 1978. ASF-HAD-positive pig samples arrived mostly from the Southeastern and Southern regions. The virus spread from Paracambi city in the Southeastern region to the Southern region. All cities where ASFV was isolated are plotted.

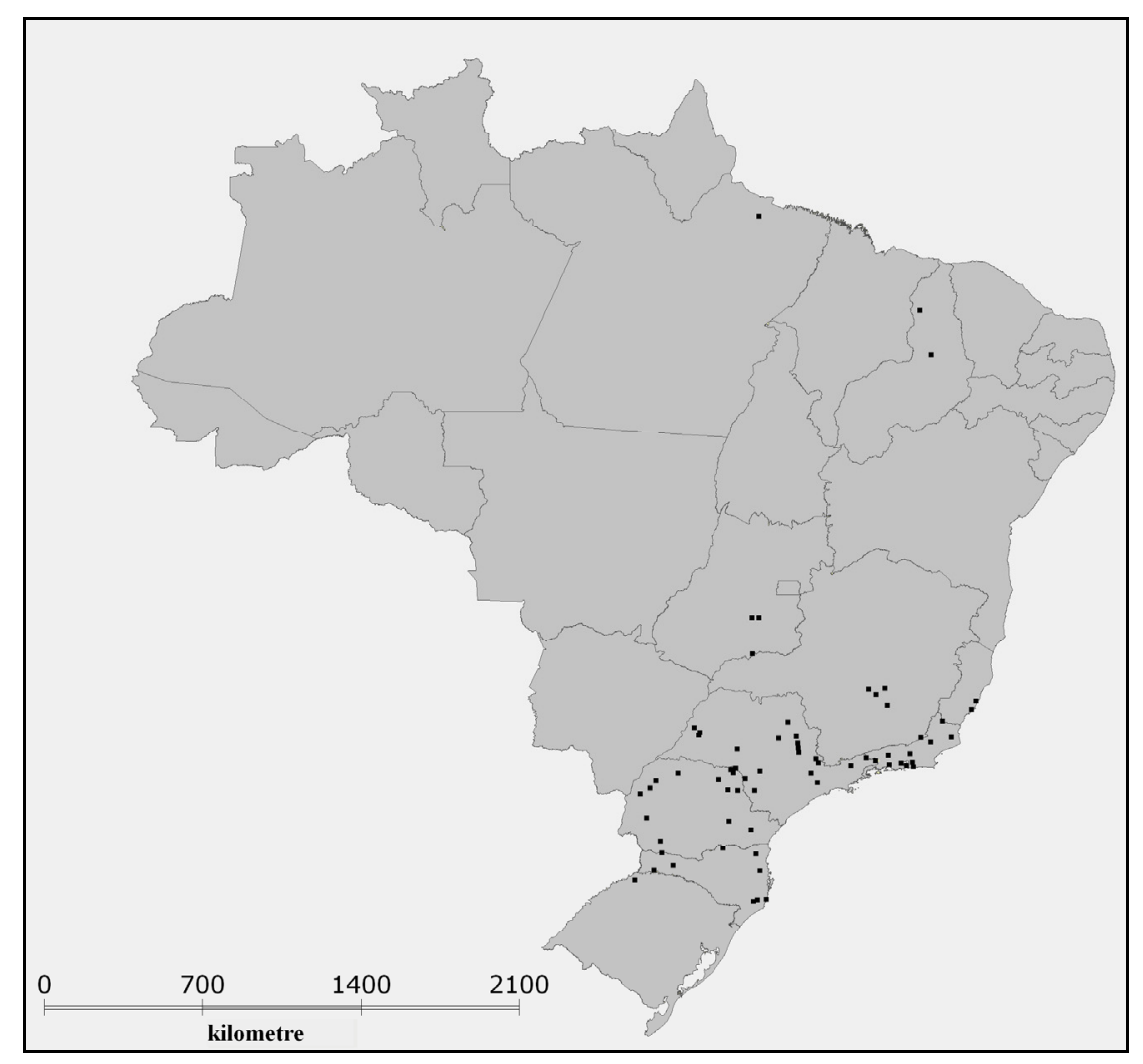

In July in the Southeastern region, HAD positive results occurred in only $2(40 \%)$ of 5 pig samples from five municipalities in RJ; 10 (22.22\%) of 45 pig samples from 36 municipalities in SP; and 3 (30\%) of 10 pig samples from eight municipalities in MG. In the Southern region, ASFV was diagnosed in 16 (41.02\%) of 39 pig samples from 28 municipalities in PR and in 11 (34.37\%) of 32 pig samples from 20 municipalities in SC. Positive results were sent to Federal and State government authorities who took the necessary sanitary measures. Because of fast, integrated action between the laboratory and surveillance services, ASFV- positive samples decreased from 74 (48.36\%) of 153 in June to 56 (33.53\%) of 167 in July and to $0 \%$ in August (Table 2). To be considered negative, a sample was tested by HAD until the 3rd passage (ANDRADE, 1981). Simultaneously, ASFV antibody detection increased from $17.89 \%$ in June to $52.04 \%$ in August (Table 2).
In September, ASFDL received a total of 199 pig samples (Table 2) from 32 municipalities in the Northern, Northeastern and Mid-Western regions: 3 from the state of Pará (PA), 18 from Pernambuco (PE), 1 from Paraíba (PB), 6 from Ceará (CE), 2 from Alagoas (AL), 1 from Sergipe (SE) and 1 from Goiás (GO). In addition, samples arrived from 16 municipalities in the Southeastern region: 3 from RJ, 9 from MG and 4 from SP; and from 39 municipalities in the Southern region: 20 from $\mathrm{PR}, 7$ from SC and 12 from RS. In four pig serum samples, 3 from PE and 1 from PR, antibodies against ASFV were detected. Because pigs with peracute or acute ASF caused by high virulent ASFV often die before developing antibodies, increasing ASF antibody detection and decreasing mortality rates in August indicated a modification in the ASF disease form, with the potential prevalence of lower virulence ASFV strains (HESS, 1981). In October, 
November and December, ASFDL received 2,958 pig samples, among which 2,930 pig serum samples were tested by IEOP, and 301 were positive. During this trimester, ASFV was detected by HAD and confirmed by IIF in just one pig tissue sample, which was registered under Lab. code 674.1 Dec. 14th from Itabirito city, MG (Table 2).

During the emergency phase of the ASF eradication program from June to July, ASFV was detected by HAD in 96 of 214 municipalities surveyed in 11 Brazilian states (Figure 2). The distribution of ASFV detection indicated that the virus spread from Paracambi in the Southeast to municipalities in the Southern region following main roads that had high levels of animal transport by truck. The number of ASFV detections in the entire country dropped from 131 in 1978 to 17 in 1979 and zero in 1980; there was an increase to seven detections in 1981 and then none in the period 1982-1984 (MINISTÉRIO DA AGRICULTURA, 1984). During active surveillance in the period from 1980 to 1984 , the entire herd of breeding pigs from each municipality and a selection of finishing pigs from small farms were tested. Serological studies performed in PR, SC and RS from March 1980 to March 1981 aiming to improve serological diagnosis determined that all IEOP-reactive pig samples had to be retested by IIF for a definitive result (LYRA et al., 1981). From 1980 to 1984, 288,369 pig serum samples were tested, yielded 128 reactive results distributed as follows: 80 in 1980; 48 in 1981, and zero from 1982 to 1984 (MINISTÉRIO DA AGRICULTURA, 1984; LYRA et al., 1986).

\section{ASFV population virulence heterogeneity in Brazilian outbreaks}

FORMS were filled out with information about pig herds with ASF infection or suspicion of ASF infection. The information included state, municipality, sample number, sample shipment date, health conditions of pigs with suspected ASF infection, and diagnostic results from the laboratory.
Moreover, information such as disease description, mortality rates, and number of affected pigs in herd could be found in the FORMS. A majority of the FORMS were lost during the last thirty years, but some FORMS from the emergency phase in PR were found, and the ASF data was matched against ASF HAD detections (Tables 3A and 3B).

In $\mathrm{PR}$, of 58 samples, 25 were ASFV-positive in the first, second or third passage of the leukocyte cultures. Twenty FORMS corresponding to $80 \%$ of the positive results could be investigated. These FORMS were associated with 18 distinct municipalities (Figure 3). The HAD detections of ASFV were matched against data from the respective FORMS. Relevant data about ASFVpositive pig herds such as the number of infected animals (1,360), animals with disease signs (363) and number of dead animals (330) from nineteen pig herds were reported. The main ASF clinical sign descriptors in the FORMS were fever, anorexia, recumbence, flushing and/or cyanotic skin, particularly over the abdomen and extremities, blotching of the ears, diarrhea (mucoid and bloody), hemorrhages in the skin, dyspnea, vomiting, and thick whitish discharges from the nose and eyes. Some neurologic signs were reported, including tremors, paresis of hind legs and/or swaying gait, with hind legs appearing weak. Although some disease descriptors suggested the occurrence of the acute or sub-acute disease, the rapid decrease in mortality rates in the ASF outbreaks in PR from June $(41.5 \%)$ to July $(0.16 \%)$ indicated a mild or less virulent ASF infection. The number of affected pigs also decreased concomitantly (Tables $3 \mathrm{~A}$ and $3 \mathrm{~B}$ ). Similarly, Vigario et al. (1981) observed significant changes in the clinical form of ASF outbreaks in Portugal in 1960. The authors showed that ASF infection moved from high to low virulence, with a parallel decrease in mortality rates to levels below 5\%. The Portuguese ASF outbreaks occurred in cycles of four to six years: 1962, 1966, 1972 and 1977. 
Figure 3. Distribution of ASFV in municipalities of the state of Paraná screened in June and July 1978. Black dot $=$ ASFV negative results, gray dot $=$ ASFV positive by HAD. Circles indicate municipalities from which the FORMS were analyzed.

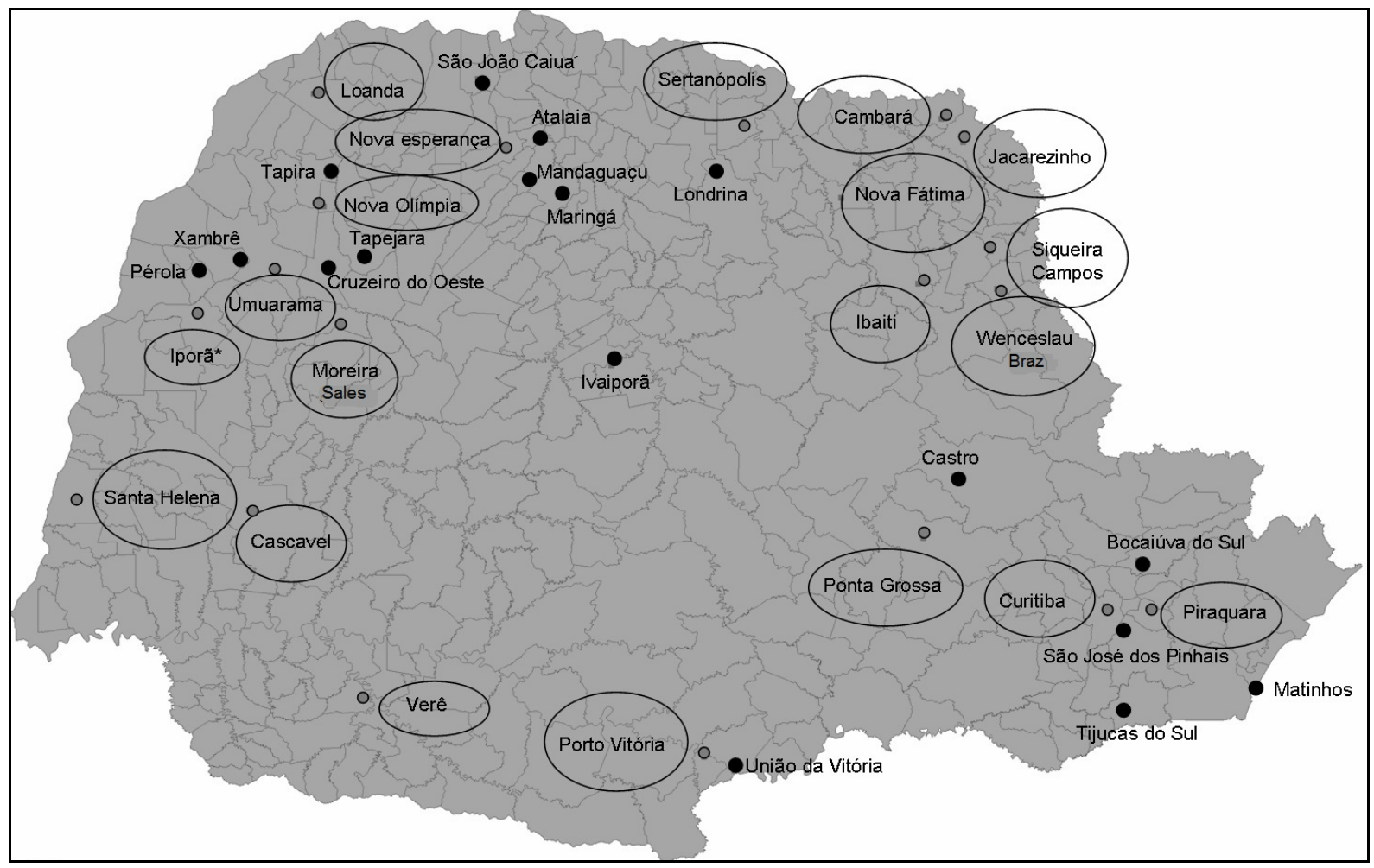

The ASF disease reached PR one month after the first outbreak in Paracambi, which was possibly associated with a Portuguese outbreak, because it was diagnosed in pigs that were fed leftover meals from flights arriving from Portugal or the Iberian Peninsula. Antigen preparations from the Lisbon 60 strain detected ASF antibodies in $100 \%$ of the Brazilian positive experimental samples tested, further supporting the possible connection between the Brazilian and Portuguese outbreaks (PAN et al., 1982; PERITZ, 1981).

The ASF outbreaks in Paracambi were considered highly virulent, although the rapid decrease in mortality rates suggested that the initial rates were enhanced by poor sanitary conditions, including the use of garbage as feed, dirty housing and the incidence of other concurrent diseases. Mebus and Schlafer (1982) suggested that the high mortality in Brazilian outbreaks was more influenced by sex, age and general pig health status. In fact, Lyra (1980) first established that ASF in Brazil had characteristics of a low virulence infection based on clinical course and low mortality rates. In 1978, ASF outbreaks also occurred in the Dominican Republic and Haiti (HESS, 1981; MEBUS, DARDIRI, 1979; MEBUS et al., 1978; RIVERA, 1981). In the Dominican Republic, pig deaths since February 1978 had been attributed to hog cholera and not ASF disease, and the ASF diagnosis was obtained five months later on July 6 in PIADC (RIVERA, 1981). Similarities among the ASF outbreaks in Brazil, the Dominican Republic and Haiti include the involvement of pig farms with poor conditions regarding pig health, sanitary measures and housing facilities (LYRA, 1981; RIVERA, 1981).

The Brazilian ASFV population heterogeneity was evidenced when strains isolated in Brazil and in the Caribbean islands, named Western Hemisphere 
isolates, were assayed in live pigs under rigorous control, and resulted in mortality rates ranging from 0 to $25 \%$, a characteristic range of low to moderate virulence strains. Moreover, the PIADC ASF expert team never isolated high virulence strains from Brazilian outbreaks, strongly suggesting the existence of a heterogeneous virus population sheltering ASFV particles from low to moderate virulence strains (MEBUS; SCHAFLER, 1982). Hess (1981) suggested that in a heterogeneous population of one virus isolate, the dominance of certain members could affect the way the disease developed. In agreement, Carnero (1982), studying ASFV field samples, suggested that virulence in one ASF outbreak was defined by the dominant virus strain, which would drive disease manifestation. During an ASF outbreak, control measures more quickly eliminate highly virulent strains. Consequently, pigs infected with lowvirulence strains could survive with unapparent or subclinical infections, as was observed in several municipalities in $\mathrm{PR}$ where the death rates of infected pigs fell below 1\% (Table 3A, 3B). As Garcia-Barreno (1986) observed, ASFV isolated in outbreaks outside the African continent were less virulent. Pigs chronically infected with low-virulent ASFV strains with no presence of clinical signs can harbor and disseminate the virus for as long as they live, and are believed to play a role in maintaining the disease (SÁNCHEZ-VIZCAÍNO, 1999).

In 1978, HAD was the principal method of ASF diagnosis. Although ASFV induction of HAD phenomena was not associated with virulence, the HAD diagnoses reflected differences in the ASFV isolation profiles (BORCA et al., 1998). In the two first months of the ASF eradication program's emergency phase (June and July, 1978), 130 samples inoculated in leukocyte cultures elicited HAD in swine erythrocytes. In 95 samples, the virus was detected in the first passage of leukocyte cultures. However, in 28 pig samples the virus could be isolated only after the second passage, and in 7 samples only after the third passage. These results can be further analyzed in terms of time and geographic origin of the samples. In early June, $100 \%$ of ASFV samples from RJ were detected in the first passage, while the majority of HADpositive samples that required a second and third passages arrived at the end of June and came from towns in the countryside of SP, PR and then SC. If the development of the acute and sub-acute forms of the disease depend on virus titer or dose at infection (HESS, 1981), it is plausible that samples tested at the end of June did not shelter high enough titers or virulent particles to induce HAD directly in the first passage. On the other hand, virus replication in pigs could be inhibited by the presence of humoral antibodies against ASFV. In this case, virus replication in leukocyte cultures could have amplified the virus titer until a HAD threshold was reached after the second or third passages.

The physiological function of HAD has yet to be elucidated. Haemadsorption induced by ASFV infection of leukocytes may allow for the adhesion of virus particles on erythrocytes, thus promoting virus spread within the host (BORCA et al., 1994; MALMIQUIST, 1962; RODRIGUEZ et al., 1993). The capacity of ASFV to elicit HAD was associated with the external virus envelope CD2v glycoprotein, translated in infected macrophages, which is homologous to the CD2 protein in leukocyte membrane surfaces (BORCA et al., 1994; RUIZ-GONZALVO et al., 1996). Moreover, Borca et al. (1998) observed alterations in virus replication efficiency in pigs infected with a CDv2 genedeleted virus. Alterations included delays in spread and replication, in generalization of infection, and a 100 - to 1,000 -fold reduction in virus titers in lymphoid tissue and bone marrow. Given the current evidence, the correlation among virus titer, HAD induction in the first, second or third passages of leukocyte cultures, and disease course warrants more studies. 
Table 3A. ASFV diagnostics in the state of Paraná, June 1978. Eleven FORMS from pig herds with suspected ASF infection that was later confirmed by HAD test.

\begin{tabular}{|c|c|c|c|c|c|c|}
\hline $\begin{array}{l}\text { (PR File) } \\
\text { Sample } \\
\text { number }\end{array}$ & $\begin{array}{c}\text { Shipment } \\
\text { Date }\end{array}$ & Municipality & $\begin{array}{c}\text { Infected } \\
\text { Pigs }\end{array}$ & $\begin{array}{l}\text { Sick/ } \\
\text { [date } \\
\text { offirst] }\end{array}$ & $\begin{array}{c}\text { Dead (\%) } \\
\text { [date } \\
\text { of first] }\end{array}$ & $\begin{array}{l}\text { Laboratory } \\
\text { diagnosis }\end{array}$ \\
\hline $\begin{array}{l}\text { (80) } 41.1 \\
\text { (81) } 42.1\end{array}$ & $19 / 06$ & Jacarezinho & 300 & $\begin{array}{c}272 \\
{[10 / 04]^{*}}\end{array}$ & $\begin{array}{c}272(90 \%) \\
* *\end{array}$ & $\begin{array}{c}\text { HAD }+1^{\mathrm{a}} \# \\
\text { FAT (Sp., LN) } \\
\text { HAD }[22 / 06]\end{array}$ \\
\hline (84) 36.1 & $19 / 06$ & Cambará & 19 & $01[15 / 06]$ & $\begin{array}{l}01(5 \%) \\
{[18 / 06]}\end{array}$ & $\begin{array}{c}\mathrm{HAD}+1^{\mathrm{a}} \# \\
{[22 / 06]}\end{array}$ \\
\hline (91) 48.1 & $20 / 06$ & $\begin{array}{c}\text { Wenceslau } \\
\text { Braz }\end{array}$ & 58 & 21 & $\begin{array}{c}21(36 \%) \\
{[05 / 06]}\end{array}$ & $\begin{array}{c}\text { HAD }+1^{\mathrm{a}} \# \\
\text { FAT (Sp., LN) } \\
{[23 / 06]}\end{array}$ \\
\hline (133) 95.1 & $20 / 06$ & $\begin{array}{c}\text { Nova } \\
\text { Esperança }\end{array}$ & 21 & $02[19 / 06]$ & $02(9.5 \%)$ & $\begin{array}{c}\mathrm{HAD}+2 \# \\
{[24 / 06]}\end{array}$ \\
\hline (149) 97.1 & $23 / 06$ & Piraquara & 21 & $06[17 / 06]$ & $06(28.5 \%)$ & $\begin{array}{c}\text { HAD+2\# } \\
\text { FAT (Sp., LN) } \\
{[27 / 06]}\end{array}$ \\
\hline (181) 129.1 & $27 / 06$ & Santa Helena & 146 & $02[15 / 06]$ & $\begin{array}{c}02(1.36 \%) \\
{[27 / 06]}\end{array}$ & $\begin{array}{c}\text { HAD+1\# } \\
\text { FAT (Sp.) [30/06] }\end{array}$ \\
\hline (184) 132,1 & $26 / 06$ & Ibaiti & 150 & $01[26 / 06]$ & $01(0.6 \%)$ & $\begin{array}{c}\mathrm{HAD}+2 \# \\
{[30 / 06]}\end{array}$ \\
\hline (185) 133.1 & $26 / 06$ & Iporã & 30 & 05 & $05(16.6 \%)$ & $\begin{array}{c}\text { HAD }+2 \# \\
\text { FAT (Sp.) [30/06] }\end{array}$ \\
\hline (186) 134.1 & $28 / 06$ & $\begin{array}{l}\text { Wenceslau } \\
\text { Braz }\end{array}$ & 04 & 01 & $01(25 \%)$ & $\begin{array}{c}\text { HAD }+2 \# \\
\text { FAT (Sp., LN, Li.) } \\
{[30 / 06]}\end{array}$ \\
\hline (212) 160.1 & $29 / 06$ & Jacarezinho & 22 & $\begin{array}{c}15 \\
{[15 / 06]}\end{array}$ & $09(40 \%)$ & $\begin{array}{c}\mathrm{HAD}+1 \# \\
{[5 / 07]} \\
\end{array}$ \\
\hline Total: 11 & $19-29 / 06$ & 10 & 771 & 326 & $320(41.5 \%)$ & \\
\hline
\end{tabular}

Abbreviations: $\mathrm{Sp} .=$ spleen, $\mathrm{LN}=$ lymph nodes, $\mathrm{Li} .=$ liver, $\mathrm{HAD}=$ haemadsorption test, $\mathrm{HAD}+1 \#=$ HAD positive in first passage in leukocyte culture, $\mathrm{HAD}+2 \#=\mathrm{HAD}$ positive in second passage in leukocyte culture, FAT = fluorescent antibody test.

*Sick pig reared on garbage dump.

**Date of first death of pig was not registered. 
Table 3B. ASFV diagnostics in the state of Paraná, July 1978. Nine FORMS from pig herds with suspected ASF infection that was later confirmed by HAD test.

\begin{tabular}{|c|c|c|c|c|c|c|}
\hline $\begin{array}{l}\text { (PR File) } \\
\text { Sample } \\
\text { number }\end{array}$ & $\begin{array}{c}\text { Shipment } \\
\text { Date }\end{array}$ & Municipality & $\begin{array}{c}\text { Infected } \\
\text { Pigs }\end{array}$ & $\begin{array}{c}\text { Sick/ } \\
\text { [date } \\
\text { of first] }\end{array}$ & $\begin{array}{c}\text { Dead/ (\%) } \\
\text { [date } \\
\text { of first] }\end{array}$ & $\begin{array}{c}\text { Laboratory } \\
\text { diagnosis }\end{array}$ \\
\hline 168.1 & $04 / 07$ & Curitiba & 120 & $\begin{array}{c}01 \\
{[30 / 6]}\end{array}$ & $01(0.8 \%)$ & $\begin{array}{c}\text { HAD+2\# } \\
{[07 / 07]}\end{array}$ \\
\hline 172.1 & $04 / 07$ & Verê & 50 & 04 & $02(4 \%)$ & $\begin{array}{c}\text { HAD+1\# } \\
\text { FAT (Sp., LN, Li. } \\
{[07 / 07]}\end{array}$ \\
\hline (235) 183.1 & $05 / 07$ & Sertanópolis & 50 & $\begin{array}{c}01 \\
{[03 / 07]}\end{array}$ & $01(2 \%)$ & $\begin{array}{c}\text { HAD+2\# } \\
\text { FAT (Sp.) } \\
{[07 / 07]}\end{array}$ \\
\hline (256) 204.1 & $07 / 07$ & Nova Fátima & 11 & $\begin{array}{c}01 \\
{[01 / 07]}\end{array}$ & $01(9 \%)$ & $\begin{array}{c}\text { HAD+1\# } \\
\text { FAT (Sp.) } \\
{[10 / 07]}\end{array}$ \\
\hline (263) 211.1 & $07 / 07$ & Loanda & 50 & 02 & $\begin{array}{l}01(2 \%) \\
{[07 / 07]}\end{array}$ & $\begin{array}{c}\text { HAD+2\# } \\
{[12 / 07]}\end{array}$ \\
\hline (266) 215.1 & $07 / 07$ & $\begin{array}{l}\text { Siqueira } \\
\text { Campos }\end{array}$ & 124 & $\begin{array}{c}01 \\
{[07 / 07]}\end{array}$ & $\begin{array}{c}01(0.8 \%) \\
{[07 / 07]}\end{array}$ & $\begin{array}{c}\text { HAD+1\# } \\
{[13 / 07]}\end{array}$ \\
\hline (267) 216.1 & $07 / 07$ & Ponta Grossa & 49 & 01 & $01(2.04 \%)$ & $\begin{array}{c}\text { HAD+3\# } \\
{[13 / 07]}\end{array}$ \\
\hline (329) 272.1 & $20 / 07$ & Cascavel & 112 & $\begin{array}{c}25 \\
{[17 / 07]}\end{array}$ & $01(0.89 \%)$ & $\begin{array}{c}\text { HAD+3\# } \\
{[24 / 07]}\end{array}$ \\
\hline (343) 286.1 & $19 / 07$ & Nova Olímpia & 23 & $\begin{array}{c}01 \\
{[17 / 07]}\end{array}$ & $01(4.34 \%)$ & $\begin{array}{c}\mathrm{HAD}+1 \# \\
{[28 / 07]}\end{array}$ \\
\hline Total: 09 & $4-19 / 07$ & 09 & 589 & 37 & $10(0.16 \%)$ & \\
\hline
\end{tabular}

Abbreviations: $\mathrm{Sp} .=$ spleen, $\mathrm{LN}=$ lymph nodes, $\mathrm{Li} .=$ liver, $\mathrm{HAD}=$ haemadsorption test, $\mathrm{HAD}+1 \#=\mathrm{HAD}$ positive in first passage in leukocytes culture, $\mathrm{HAD}+2 \#=\mathrm{HAD}$ positive in second passage in leukocytes culture, $\mathrm{HAD}+3 \#=\mathrm{HAD}$ positive in third passage in leukocytes culture, FAT $=$ fluorescent antibody test.

European and American laboratories have established several lines of research to understand and control ASFV, including strains isolated in Brazil (WESLEY; PAN, 1981; DIXON; WILKINSON, 1988; GALLARDO et al., 2009; NIX et al., 2006). Since 1981, the genetic variation among several field isolates of ASFV was assessed by analysis of enzymatic restriction fragments. Wesley and Pan (1981) studied five ASFV isolates identified as Vero cell-adapted, including Lisbon 60, V-6, Haiti, Brazil and Dominican Republic (DR). Using restriction endonuclease digestion, the authors demonstrated the existence of different lengths of SmA1 and EcoR-I restriction fragment patterns as a probable consequence of deletion or genetic rearrangement of the virus genome. Furthermore, it was demonstrated that variation in length of restriction fragments can be associated with virulence (NEILAN et al., 2002). A high level of variability in the virulence of ASFV field isolates from inside and outside Africa was demonstrated by restriction length fragment polymorphism (RFLP). After the advent of cloning and nucleotide sequencing techniques, the relation among European, Caribbean and South American field isolates was established (DIXON; WILKINSON, 1988; IYER et al., 2006; PAN et al., 1988; TULMAN; ROCK, 2001). Specific analysis of ASFV genomes by restriction enzyme site mapping and by partial sequencing of the gene encoding the major capsid protein $\mathrm{p} 72$ demonstrated that isolates from Europe, the Caribbean, South America, and Western and Central Africa are closely related to each 
other (CHAPMAN et al., 2008; GALLARDO et al., 2009; NIX et al., 2006; VILLIERS et al., 2010).

Despite this body of work, the epidemiology of ASF, including virulence, pathogenic potential, and host range, is not fully elucidated. ASFV genomic studies provide information on conserved regions and coded antigenic proteins that, if associated with virus heterogeneity, will contribute to the understanding of molecular viral epidemiology (GALLARDO et al., 2009; NIX et al., 2006; YANEZ et al., 1995). The ASFV genome is a DNA molecule which contains a central conserved region and variable terminal regions composed of internal inverted complementary repetitions arranged in tandem, including the five multigene families (MGF 100, 110, 300, 360 and 505/530) where genetic variation mainly occurs (CHAPMAN et al., 2008). The genetic variability of several genes associated with virulence and host range suggested that low virulence could be associated with a decrease in the number of genes in families 360 and 505/530 following mutations with large deletions (CHAPMAN et al., 2008; NEILAN et al., 2002; TULMAN; ROCK, 2001).

\section{Conclusions}

Following the outbreak of African swine fever (ASF) in Brazil in 1978, an official laboratory for ASF diagnosis (ASFDL) and a successful ASF eradication program were established with impressive efficiency, thanks to international aid and the competence of the Brazilian ASFDL team. In the state of Paraná, the rapid decrease in mortality rates suggested a change in the form of the disease. In this regard, two aspects should be considered: 1) The initial high rates of mortality were aggravated by poor sanitary conditions, including the use of garbage as feed, dirty swine housing facilities and the simultaneous occurrence of other diseases, especially salmonellosis; and 2) The presence of low virulence strains of ASFV. The sub-clinical course of ASF caused by virus strains of low virulence increases the threat, because the virus can enter a country insidiously. Advances in cellular and molecular biology have corroborated earlier studies on ASFV virulence, and have highlighted the importance of establishing and maintaining secure measures to prevent ASFV entrance into ASF-free countries. ASF was and still is an economic disaster for small pig farmers, the pork industry, food security and the livestock market. The Brazilian experience provides valuable information in light of the current worldwide ASF situation. For instance, Russian authorities recently suspended the importation of porcine meat from the European Union (EU) due to ASF outbreaks in EU countries, although Russia has spent approximately US $\$ 1$ billion in unsuccessful attempts to control ASF in its own territories.

\section{Dedication and Acknowledgements}

This work is dedicated to the memory of Dr. Cesar Eduard H. Rozas, the friendliest vet in the ASF eradication program, to Dr. C. M. Andrade and his team who established the ASFDL, and to Drs. D. Lyra and M. Nakajima of the ASF-Laboratory of LANARA/MAPA. We are grateful to Ms. V. S. F. Sousa from the former LANAGRO/MG library and to Dr. A. P. Cavalcante of the Suidae Health Division for designing the maps. This work was supported by the Ministry of Agriculture, Livestock and Supply.

This manuscript was reviewed by a professional science editor and by a native English-speaking copy editor to improve readability.

\section{References}

ANDRADE, C. M. African swine fever in Brazil: three years experience in the laboratory. In: CEC/FAO EXPERT CONSULTATION IN AFRICA SWINE FEVER RESEARCH SEMINAR, 1981, Sardinia. Proceedings... Sardinia: Ed. P. J. Wilkinson, 1981. p. 152-160. 
Diagnóstico laboratorial da peste suína africana no Brasil. Informativo LANARA, Brasília, v. 2, n. 10, p. 20-24, 1980.

ARZT, J.; WHITE, W. R.; THOMSEN, B. V.; BROWN, C. C. Agricultural diseases on the move early in the third millennium. Veterinary Pathology, Greenport, v. 47, n. 1, p. $15-27,2010$.

BASTO, A. P.; NIX, R. J.; BOINAS, F.; MENDES, S.; SILVA, M. J.; CARTAXEIRO, C.; PORTUGAL, R. S.; LEITÃO, A.; DIXON, L. K.; MARTINS, C. Kinetics of African swine fever virus infection in Ornithodoros erraticus ticks. Journal of General Virology, London, v. 87, n. 7, p. 1863-1871, 2006.

BASTOS, A. D. S.; PENRITH, M. L.; MACOME, F.; PINTO, F.; THOMSON, G. R. Co-circulation of two genetically distinct viruses in an outbreak of African swine fever in Mozambique: no evidence for individual co-infection. Veterinary Microbiology, Amsterdam, v. 103, n. 3-4, p. 169-182, 2004.

BOINAS, F. S.; HUTCHINGS, G. H.; DIXON L. K.; WILKINSON P. J. Characterization of pathogenic and non-pathogenic African swine fever virus isolates from Ornithodoros erraticus inhabiting pig premises in Portugal. Journal of General Virology, London, v. 85, n. 8, p. 2177-2187, 2004.

BOOL, P. H.; ORDAS, A.; SANCHEZ BOTIJA, C. The diagnosis of African swine fever by immunofluorescence. Bulletin L'Office International des Epizooties, Paris, v. 72, n. 7-8, p. 819-839, 1969.

BORCA, M. V.; CARRILLO, C.; ZSAK, L.; LAEGREID, W. W.; KUTISH, G. F.; NEILAN, J. G.; BURRAGE, T. G.; ROCK, D. L. Deletion of a CD2-Like Gene, 8-DR, from African swine fever virus affects viral infection in domestic swine. Journal of Virology, Birmingham, v. 72, n. 4, p. 2881-2889, 1998.

BORCA, M. V.; KUTISH, G. F.; AFONSO, C. L.; IRUSTA, P.; CARRILLO, C.; BRUN, A.; SUSSMAN, M.; ROCK, D. L. An African swine fever virus gene with similarity to the T- lymphocyte surface-antigen $\mathrm{Cd} 2$ mediates haemadsorption. Virology, Washington, v. 199, n. 2, p. 463-468, 1994.

CARNERO, R. Fiebre porcina Africana: conocimiento de la enfermedad. San Jose: IICA, 1982. 244 p.

CHAPMAN, D. A.; TCHEREPANOV, V.; UPTON, C.; DIXON, L. K. Comparison of the genome sequences of non-pathogenic and pathogenic African swine fever virus isolates. Journal of General Virology, London, v. 89, n. 2, p. 397-408, 2008.
DIXON, L. K. The structure and function of the African swine fever virus genome. Revue Scientifique et Technique, Paris, v. 5, n. 2, p. 469-475, 1986.

DIXON, L. K.; WILKINSON, P. J. Genetic diversity of African swine fever virus isolates from soft ticks (Ornithodoros moubata) inhabiting warthog burrows in Zambia. Journal of General Virology, London, v. 69, n. 12, p. 2981-2993, 1988.

GALLARDO, C.; MWAENGO, D. M.; MACHARIA, J. M.; ARIAS, M.; TARACHA, E. A.; SOLER, A.; OKOTH, E.; MARTIN, E.; KASITI, J.; BISHOP, R. P. Enhanced discrimination of African swine fever virus isolates through nucleotide sequencing of p54, p72, and pB602L (CVR) genes. Virus Genes, Heidelberg, v. 38, n. 1, p. 85-95, 2009.

GARCIA-BARRENO, B.; SANZ, A.; NOGAL, M. L.; VINUELA, E.; ENJUANES, L. Monoclonal antibodies of African swine fever virus: antigenic differences among field virus isolates and viruses Passaged in cell culture. Journal of Virology, London, v. 58, n. 2, p. 385392, 1986.

HESS, W. R. African swine fever: reassessment. Advances in Veterinary Science and Comparative Medicine, New York, v. 25, p. 39-69, 1981.

HESS, W. R.; OETRAY, D. E. The use of leukocyte cultures for diagnosing African swine fever (ASF). Bulletin of Epizootic Diseases of Africa, Nairobi v. 8, p. 317-320, 1960.

IYER, L. A.; BALAJI, S.; KOONIN, E. V.; ARAVIND, L. Evolutionary genomics of nucleo-cytoplasmic large DNA viruses. Virus Research, Philadelphia, v. 117, n. 1, p. 156-184, 2006.

LYRA, T. M. P. A peste suína africana de baixa mortalidade. Boletim da Defesa Sanitária Animal, Brasília, número especial, p. 50-59, 1980.

La erradicación de la peste porcina africana en el Brasil, 1978-1984. Revue Scientifique et Technique, Paris, v. 25, n. 1, p. 93-103, 2006.

. Program of control against swine fever in Brazil. In: CEC/FAO Expert Consultation in Africa Swine Fever Research Seminar, 1981 Sardinia. Proceedings... Ed. P. J. Wilkinson, 1981, p. 25-35, Sardinia, Italy.

LYRA, T. M. P.; PAVEZ, M. M.; ANDRADE, C. M. Serological study of African swine fever in the pig population of southern Brazil. In: CEC/FAO EXPERT CONSULTATION IN AFRICA SWINE FEVER RESEARCH SEMINAR, 1981, Sardinia. Proceedings... Sardinia: Ed. P. J. Wilkinson, 1981. p. 47-62. 
LYRA, T. M. P.; SARAIVA, V. E. V.; LAJE, G. R. H.; SAMARCOS, M. S. R. Eradication of African swine fever from Brazil. Revue Scientifique et Technique, Paris, v. 5, n. 3, p. 771-787, 1986.

MAC DANIEL, H. A. African swine fever. In: LEMAN, A.D.; GLOCK, R.D.; MENGELING, W.L.; PENNY, R.H.C.; SCHOLL, E.; STRAW, B. Disease of swine. $5^{\text {th }}$ ed. Ames: Ed. Iowa state University Press, 1981. p. 237245.

MACHADO JUNIOR, T. L. The development of aids to the prevention and control of exotic animal diseases in Brazil. 1990. PhD (Thesis) - Department of Agriculture. Veterinary Epidemiology and Economics Research Units. University of Reading, Reading, UK.

MALMIQUIST, W. A. Propagation, modification and hemadsorption of African swine fever virus in cell cultures. American Journal of Veterinary Research, Schaumburg, v. 23, p. 241-247, mar. 1962.

MALOGOLOVKIN, A.; YELSUKOVA, A.; GALLARDO, C.; TSYBANOV, S.; KOLBASOV, D. Molecular characterization of African swine fever virus isolates originating from outbreaks in the Russian Federation between 2007 and 2011. Veterinary Microbiology, Amsterdam, v. 158, n. 3-4, p. 415-419, 2012.

MEBUS, C. A.; DARDIRI, A. H. Additional characteristic of disease caused by African swine fever viruses isolated from Brazil and the Dominican Republic. In: ANNUAL MEETING OF US ANIMAL HEALTH ASSOCIATION, 83., 1979, Buffalo. Proceedings... Buffalo: USAHA, 1979. p. 227-239.

MEBUS, C. A.; DARDIRI, A. H.; HAMDY, F. M. Some characteristics of African swine fever viruses isolated in Brazil and Dominican Republic. In: ANNUAL MEETING OF US ANIMAL HEALTH ASSOCIATION, 82., 1978, Buffalo. Proceedings... Buffalo: USAHA, 1978. p. 232-236.

MEBUS, C. A.; MAC VICAR, J. W.; DARDIRI, A. H. Comparison of the pathology of high and low virulence African swine fever virus infection In: $\mathrm{CEC} /$ FAO EXPERT CONSULTATION IN AFRICA SWINE FEVER RESEARCH SEMINAR, 1981, Sardinia. Proceedings... Sardinia: Ed. P. J. Wilkinson, 1981. p. 183-194.

MEBUS, C. A.; SCHAFLER, D. H. African swine fever in americas: a changing disease. In: FIRST INTERNATIONAL CONFERENCE ON THE IMPACT OF VIRAL DISEASE ON THE DEVELOPMENT OF LATIN AMERICAN AND THE CARIBBEAN REGION, 1982, Rio de Janeiro. Proceedings... Rio de Janeiro: Ed. Instituto Oswaldo Cruz, 1982. v. 1, p. 198-202.
MINISTÉRIO DA AGRICULTURA. Brasil, livre da peste suína africana. Coordenação Nacional do Programa de Combate a Peste Suína. Brasília: SNDA/SDSA/ DCPD, 1984. 63 p.

MONTGOMERY, R. E. On a form of swine fever occurring in British East Africa (Kenya Colony). Journal of Comparative Pathology and Therapeutics, Bristol, v. 34, n. 3, p. 159-191, 1921.

NEILAN, J. G.; ZSAK, L.; LU, Z.; KUTISH, G. F.; AFONSO, C. L.; ROCK, D. L. Novel swine virulence determinant in the left variable region of the African swine fever virus genome. Journal of Virology, Birmingham, v. 76, n. 7, p. 3095-3104, 2002.

NIX, R. J.; GALLARDO, C.; HUTCHINGS, G.; BLANCO, E.; DIXON, L. K. Molecular epidemiology of African swine fever virus studied by analysis of four variable genome regions. Archive of Virology, New York, v. 151, n. 12 , p. $2475-2494,2006$.

OURA, C. A. L.; POWELL, P. P.; ANDERSON, E.; PARKHOUSE, R. M. E. The pathogenesis of African swine fever in the resistant bushpig. Journal of General Virology, London, v. 79, n. 6, p. 1439-1443, 1998.

PAN, I. C.; DE BOER, C. J.; HESS, W. R. African swine fever: application of immuno-electro-osmophoresis for the detection of antibody. Canadian Journal of Comparative Medicine, Ottawa, v. 36, n. 3, p. 309-316, 1972.

PAN, I. C.; HUANG, T. S.; HESS, W. R. New method of antibody detection by indirect immunoperoxidase plaque staining for serodiagnosis of African swine fever. Journal of Clinical Microbiology, Washington, D. C, v. 16, n. 4, p. 650-655, 1982.

PAN, I. C.; WHYARD, T. C.; HESS, W. R.; YUASA, N.; SHIMIZU, M. Epitopic diversity of African swine fever virus. Virus Research, Philadelphia, v. 9, n. 2-3, p. 93106, 1988.

PENRITH, M. L.; VOSLOO, W. Review of African swine fever: transmission spread and control. Journal of South African Veterinary Association, Durbanville, v. 80, n. 2, p. 58-62, 2009.

PERITZ, F. J. The dangerous deviant - African swine fever in Latin America since 1978. Surveillance, FAO, Santiago, v. 8, n. 3, p. 5-7, 1981.

RIVERA, E. M. African swine in the Dominican Republic. In: CEC/FAO EXPERT CONSULTATION IN AFRICA SWINE FEVER RESEARCH SEMINAR, 1981, Sardinia. Proceedings... Sardinia: Ed. P. J. Wilkinson, 1981. p. 17-124. 
RODRIGUEZ, J. M.; YANEZ, R. J.; ALMAZAN, F.; VINUELA, E.; RODRIGUEZ, J. F. African swine fever virus encodes a cd2 homolog responsible for the adhesion of erythrocytes to infected cells. Journal of Virology, London, v. 67, n. 9, p. 5312-5320, 1993.

RUIZ-GONZALVO, F.; RODRIGUEZ, F.; ESCRIBANO, J. M. Functional and immunological properties of the baculovirus-expressed hemagglutinin of African swine fever virus. Virology, Washington, v. 218, n. 1, p. 285-289, 1996.

SÁNCHEZ-VIZCAÍNO, J. M. African swine fever. In: STRAW, B. E.; D'ALLAIRE, S.; MENGELING, W. L.; TAYLOR, D. J. (Ed.). Diseases of swine. $8^{\text {th }}$ ed. Ames: Iowa State University Press, 1999. p. 93-102.

TULMAN, E. R.; ROCK, D. L. Novel virulence and host range genes of African swine fever virus. Current Opinion in Microbiology, Paris, v. 4, n. 4, p. 456-461, 2001.

VIGARIO, J. D.; CASTRO PORTUGAL, F. L.; FESTAS, M. B.; VASCO, S. G. The present state of African swine fever in Portugal. In: CEC/FAO EXPERT CONSULTATION IN AFRICA SWINE FEVER RESEARCH SEMINAR, 1981, Sardinia. Proceedings... Sardinia: Ed. P. J. Wilkinson, 1981. p. 12-16.
VILLIERS, E. P.; GALLARDO, C.; ARIAS, M.; SILVA, M.; UPTON, C.; MARTIN, R.; BISHOP, R. P. Phylogenomic analysis of 11 complete African swine fever virus genome sequences. Virology, Washington, v. 400, n. 1, p. 128-136, 2010.

WESLEY, R. D.; PAN, I. C. Differentiation of vero celladapted African swine fever virus isolates by restriction endonuclease analysis. In: CEC/FAO EXPERT CONSULTATION IN AFRICA SWINE FEVER RESEARCH SEMINAR, 1981, Sardinia. Proceedings... Sardinia: Ed. P. J. Wilkinson, 1981. p. 240-253.

WORLD ORGANIZATION FOR ANIMAL HEALTH OIE. World animal health information. Paris: Ed. OIE, 2012. Available at: <http://web.oie.int/wahis/public>. Accessed at: 10 jun. 2012.

YANEZ, R. J.; RODRIGUEZ, J. M.; NOGAL, M. L.; YUSTE, L.; ENRIQUEZ, C.; RODRIGUEZ, J. F.; VINUELA, E. Analysis of the complete nucleotide sequence of African swine fever virus. Virology, Washington, v. 208, n. 1, p. 249-278, 1995. 